\title{
ANALISIS PARTISIPASI MASYARAKAT DALAM PEMBANGUNAN DESA SIDOREJO KECAMATAN SAWAHAN KABUPATEN NGANJUK
}

\author{
*Veril Sella Marlita ${ }^{1)}$, Sugeng Widodo ${ }^{2)}$ \\ 1) Program Studi Administrasi Publik, Universitas Kadiri, Indonesia \\ 2) Program Studi Administrasi Publik, Universitas Kadiri, Indonesia \\ *Email Korespondensi :Verilsella0@gmail.com
}

\begin{abstract}
Abstrak
Pembangunan nasional dapat dimulai dari adanya pembangunan desa. Tujuan utama dari adanya perkembangan dalam pembangunan desa adalah meningkatkan kesejahteraan masyarakat. Dalam pelaksanaan pembangunan desa perlu dilakukan dengan cara bertahap dan konsisten agar tujuan dalam mensejahterkan masyarakat dapat secara merata dan perkembangan dapat terlihat. dimana dapat disesuaikan dengan skala prioritas dan potensi yang dimiliki oleh desa tersebut, agar langkah perubahan sesuai dengan sasaran. Penelitian ini menggunakan desain deskriptif dengan menggunakan pendekatan kualitatif yang bertujuan untuk mengkaji partisipasi masyarakat di Desa Sidorejo dengan model penelitian interaktif. Hasil dari penelitian ini adalah partisipasi masyarakat di Desa Sidorejo relatif tinggi, namun perlu adanya kerjasama antara pemerintahan desa dengan masyarakat, karena terbatasnya pemberian ruang dan kesempatan kepada masyarakat untuk terlibat dalam proses pembangunandari perencanaan maupun pelaksanaan pembangunan hingga pengawasan setelah proses pembangunan dilakukan masih sangat terbatas. Karena mayoritas masyarakat hanya menerima komando dari pemerintah desa.
\end{abstract}

Kata Kunci: Partisipasi Masyarakat; Pembangunan Desa; Pemerintahan Desa.

\begin{abstract}
National development can start with rural development. The main goal of development in rural development is to promote community welfare..In the implementation of village development, it needs to be done gradually and consistently so that the goals of the welfare of the community can be evenly distributed and progress can be seen.which can be adjusted to the priority scale and the potential of the village, so that the steps for change are by the target. This study used a descriptive design using a qualitative approach that aims to examine community participation in Sidorejo Village with an interactive research model.The result of this research is that community participation in Sidorejo Village is relatively high, but there is a need for cooperation between the village government and the community, due to the limited provision of space and opportunities for the community to be involved in the development process from planning and implementing development to monitoring after the development process is still very limited. . Because the majority of the community only received commands from the village government.
\end{abstract}


Keywords: Community Participation; Village Development; Village Government.

\section{PENDAHULUAN}

Dalam mewujudkan kesejahteraan masyarakat yang landasannya terdapat di dalam Pembukaan Undang-Undang Dasar 1945 yang menyatakan bahwa "Melindungi segenap bangsa dan seluruh tumpah darah Indonesia, memajukan kesejahteraan umum, mencerdaskan kehidupan bangsa, serta ikut melaksanakan pembangunan nasional." Yang dapat ditelaah isinya bahwasanya pemerintahan desa adalah salah satu faktor penting untuk mengatur dan mengurus kehidupan masyarakat setempat sesuai daerah yang ditinggali. Untuk mewujudkan adanya kesejahteraan masyarakat perlu adanya komunikasi yang baik antara pemerintahan desa dengan masyarakat desa.Untuk itu perlu adanya peran pemerintah atau campur tangan langsung dalam mengatur kehidupan masyarakat desa.Di samping itu faktor terpenting dalam adanya kemajuan di suatu wilayah desa perlu adanya partisipasi dari masyarakat seutuhnya dalam keberhasilan pembangunan desa. Perkembangan dalam pembangunan di suatu desa memiliki tujuan utama untuk meningkatkan kesejahteraan masyarakat. Dengan begitu pembangunan desa harus dilaksanakan secara bertahap dan konsisten agar terciptanya kesejahteraan masyarakat yang semakin baik.

Dalam mewujudkan cita-cita bangsa untuk dapat mensejahterkan masyarakatnya, maka perlu adanya perubahan yang dilakukan oleh pemerintah, salah satu caranya adalah adanya pembangunan baik dari infrastruktur maupun dari sumber daya masyarakat Indonesia sendiri. Untuk mencapai kemajuan umat manusia maka perlu adanya pembangunan (Suyono \& Pramono, 2018) Dalam melaksanakan pembangunan nasional dapat dimulai dari adanya pembangunan desa, karena pemerintahan desa-lah yang menjadi sarana terdekat atau alat utama bagi pemerintahan pusat dalam mengimplementasikan regulasi yang dibuat dalam pembangunan, pemberdayaan masyarakat serta pelayanan publik karena pemerintahan desa adalah pemerintahan yang terkecil yang berhubungan sangat erat dan dekat dengan keinginan dan permintaan dari masyarakat. Oleh karena itu adanya pembangunan infrastruktur yang baik dari pemerintah merupakan faktor penunjang utama yang sangat dibutuhkan oleh masyarakat 
guna untuk meningkatkan kualitas dan kesejahteraan hidup.Pemerintah desalah yang menjadi alat untuk menyalurkan aspirasi masyarakat sesuai dengan kepentingan masyarakat. Dengan begitu jika hubungan antara masyarakat dan pemerintah desa tidak baik maka akan menyebabkan adanya penghambatan pembangunan dan ketidak pedulian masyarakat terhadap pembangunan desa. Pembangunan dapat disebut juga rangkaian usaha adanya pertumbuhan dan perubahan yang dilakukan dengan sadar oleh pemerintah dalam rangka pembinaan bangsa (Indrawidjaja et al., 2011)

Hubungan baik antara pemimpin dan masyarakat adalah kunci dari tercapainya adanya partisipasi masyarakat yang baik sehingga pembangunan dan infrastruktur terus berkembang dan mampu mensejahterakan masyarakat di desa.Di Desa Sidorejo Kecamatan Sawahan Kabupaten Nganjuk, kesadaran akan pentingnya partisipasi masyarakat dalam pembangunan desa masih sangatlah terbatas. Ada beberapa hal yang mempengaruhi mengapa partisipasi masyarakat di Desa Sidorejo Kecamatan Sawahan Kabupaten Nganjuk masih sangat terbatas karena terdapat banyaknya kendala seperti kurangnya komunikasi yang baik antara pimpinan desa, kesibukan masing-masing masyarakat serta kurangnya pendidikan tentang pentingnya perkembangan dan kemajuan desa.Kekurangan-kekurangan tersebut mengakibatkan adanya ketidak berkembangan kondisi di Desa Sidorejo Kecamatan Sawahan Kabupaten Nganjuk.

Dalam mewujudkan adanya tujuan dan cita-cita dalam pembangunan didesaSidorejo sangat diperlukan adanya kebijakan atau regulasi dari pemerintah pusat maupun pemerintah desa guna untuk membimbing dan mengarahkan tujuan apa yang ingin dicapai bersama-sama serta melakukan adanya program pembangunan desa. Adanya program kerja bukan berarti sudah menjamin akan adanya keberhasilan dalam pembangunan desa, namun dalam pembangunan desa sangat diperlukan adanya kesadaran adanya partisipasi aktif dari masyarakat desa Sidorejo untuk meningkatkan kemajuan pembangunan desa Sidorejo agar pembangunan berjalan dengan maksimal dan kesejahteraan rakyat dapat terwujud.

Untuk itu perlu adanya rancangan dalam kegiatan pembangunan yang dilakukan oleh pemerintah Desa Sidorejo dalam melakukan pembangunan yaitu dengan melibatkan 
langsung masyarakat dalam perencanaan pembangunan, dimana proses dalam perencanaan pembangunan dilakukan rapat secara terbuka atau musrengbangdes yang dihadiri oleh sebagian masyarakat untuk diadakannya sosialisasi dalam pengambilan keputusan tentang perencanaan pembangunan. Yang kemudian dalam pelaksanaan pembangunan masyarakat harusterlibat aktif pada proses pelaksanaan karena sebagian besar pekerja seharusnya diambil dari masyarakat setempat, setelah pelaksanaan pembangunan berjalan dengan baik maka perlu diadakannya pengawasan dalam pogam pembangunan yang berjalan baik dari pemerintah desa Sidorejo maupun dari masyarakat sendiri untuk mengawal proses pembangunan agar program kerja yang berkaitan dengan masyarakat dapat berjalan secara transparan. Karena keberhasilan pembangunan desa sangat bergantung dengan masyarakat desa, karena masyarakat desalah yang mengetahui masalah dan kebutuhan untuk membangun desanya, oleh karena itu seluruh masyarakat desa harusterlibat dengan segala program perencanaan, pelaksanaan serta evaluasi dari program pembangunan. (Daraba, 2017)

Dalam keadaan realitanya, tidak semua masyarakat desa Sidorejo berpartisipasi. Dengan banyak sekali alasan untuk tidak mengikuti kegiatan yang diadakan oleh pemerintah desa, hal ini disebabkan kurangnya sosialisasi yang diberikan oleh pemerintah desa yang mengakibatkan banyak masyarakat yang masih bersifat acuh dengan program kerja yang diselenggarakan oleh pemerintah desa.

Untuk mewujudkan pembangunan yang baik perlu adanya pemahaman masyarakat terhadap pentingnya partisipasi. Karena hal ini merupakan salah satu upaya pengimplementasian pembangunan partisipastif dimana pemahaman ini akan mampu berdampak adanya kesadaran dari masyarakat betapa pentingnya partisipasi masyarakat.(Sari, 2016). Tujuan dari peran masyarakat dalam proses pembangunan yang dikemukakann oleh(Indrawidjaja et al., 2011) adalah :

1. Dengan melibatkan masyarakat dalam proses pengambilan keputusan, mampu meningkatkan rasa percaya diri dari masayrakat dengan mampu mengeluarkan ide dalam proses pengambilan keputusan, sehingga masyarakat mampu menerima keputusan yang telah diputuskan dengan baik. 
2. Kualitas perencanaan dari perencanaan dan keputusan dapat didapatkan dari adanya suara masyarakat dalam perencanaan dan pengambilan keputusan.

3. Untuk mencapai tujuan bersama dengan mengajak masyarakat mampu meningkatkan rasa kebersamaan (sesnses of community)

Dari diadakannya penelitian ini memuat tujuan untuk mengetahui partisipasi masyarakat dalam pembangunan desa Sidorejo serta untuk menganalisis faktor pendukung partisipasi masyarakat yang berada di Desa Sidorejo, Kecamatan sawahan, Kabupaten Nganjuk.

\section{TINJAUAN PUSTAKA}

(Suseno \& Sunarto, 2016) dalam penelitiannya yang berjudul "Analisis Perencanaan Pembangunan Desa Berbasis Undang-Undang Desa No 6 Tahun 2014 Di Kecamatan Gunung Pati Kota Semarang" metode yang digunakan dalam penelitian ini adalah menggunakan pendekatan studi sampling, dengan maksud data dari hasil penelitian tidak dihimpun dari keseluruhan populasi melainkan hanya diambil beberapa elemen populasi. Sedangkan teknik yang digunakan dalam penelitian ini adalah teknik sampling Proporsional area cluster sampling. Sedangkan analisis data yang digunakan adalah analisis Deskriptif. Hasil atau kesimpulan dari diadakannya penelitian ini adalah dimana rencana pembangunan di wilayah Gunungpati telah melaksanakan sesuai dengan ketentuan yang tertulis dan yang berlaku pada UU No 6 Tahun 2014, Peraturan Pemerintah (PP) No 43. Dalam menentukan daftar skala prioritas dalam rencana pembangunan Kelurahan belum sepenuhnya dilakukan sesuai dengan aturan atau petunjuk pelaksanaan. Pembangunan yang bersifat skala non fisik hampir tidak terlaksana. Anggaran yang besar yang diajukan dalam Dana Skala Prioritas (DSP) menurut peneliti sulit untuk dapat terpenuhi. Peneliti berpendapat bahwa hal tersebut akan menimbulkan beban atau masalah.

Penelitian yang dilakukan oleh (Letsoin, 2015) yang berjudul “ Partisipasi Masyarakat Dalam Pelaksanaan Pembangunan Di Desa Coa Distrik Kaimana Kabupaten Kaimana" pada penelitian ini menggunakan metode penelitian yang menggunakan pendekatan kualitatif, yang memiliki sifat deskriptif. Dimana jenis penelitian ini bukan 
bersifat berupa angka.. Dan data dikelompokkan agar lebih mudah untuk diolah. Dari penelitian ini dapat disimpulkan bahwa masih banyak hambatan-hambatan kecil dalam membangun partisipasi Desa coa, namun dapat disimpulkan bahwa tingkat partisipasi desa cukup memadai dalam rangka pelaksanaan proyek PNPM-MP di Desa Coa. Dari beberapa partisipasi yang dikaji, bentuk partisipasi masyarakat sangat terlihat dalam pengerjaan proyek PNPM-MP yang khususnya pembangunan jalan 2014. Namun peran Kepala Desa Coa beserta aparatnya berperan cukup aktif dalam mendorong partisipasi masyarakat Desa Coa dalam Proyek PNPM-MP di Desa Coa.

(SIHITE \& ZAKARIA, 2017) dalam penelitiannya yang berjudul "Partisipasi Masyarakat dalam Pembangunan Desa Pada Program Gerbang Swara" dalam penelitian ini menggunakan metode penelitian bersifat Kualitatif. Dimana dalam pendekatan ini menggunakan pendekatan perkembangan politik,. Yang berfokus pada tingkat partisipasi masyarakat di Desa Bandar Tengah pada program Gerbang Swara. Teknik analisis data yang digunakan adalah teknik analisis data kualitatif. Hasil dari penelitian ini adalah partisipasi masyarakat di Desa Bandar Tengah masih sangat kurang dimana hal tersebut dapat dilihat dari kurangnya antusias masyarakat dalam menghadiri rapat perencanaan pembangunan. Peneliti dalam penelitian ini menyimpulkan empat faktor yang mempengaruhi rendahnyatingkat partisipasi masyarakat di Desa Bandar Tengah antara lain : dipengaruhi oleh latar belakang ekonomi yang kurang, tidak ditemukannya penyerahan hak milik lahan masyarakat terhadap pemerintah, kurangnya respon terhadap adanya program Gerbang Swara hal tersebut dipengaruhi oleh kiranya sosialisasi dari pihak yang berwenang untuk masyarakat, kurangnya kesadaran bahwa kegiatan pembangunan akan berjalan dengan baik jika keterlibatan dan antusias dari masyarakat tinggi.

\section{METODE PENELITIAN}

Pendekatan yang digunakan pada penelitian ini adalah pendekatan deskriptif dimana dengan menggunakan analisa kualitatif. Penelitian deskripstif merupakan penelitian yang menyajikan data-data berdasarkan masalah yang diambil, atau 
menganalisis dan melakukan interprestasi yang bersifat komperatif atau korelatif untuk memecahkan masalah pada penelitian yang diambil.

Jenis yang digunakan pada penelitian ini adalah penelitian kualitatif, merupakan penelitian yang bersifat variabel tunggal tidak ada variabel pembanding. Dalam penelitian kualitatif dapat disimpulkan dalam penelitian kualitatif merupakan gagasan baru yang belum pernah ada. Gagasan baru ini dapat berupa deskripsi dari gambaran atau objek yang sebelumnya bersifat semua atau tidak ada kejelasannya hingga perlu adanya penelitian untuk menjadikan jelas keberadaannya.(Ibrahim, 2015)

Lokasi Penelitian ini ditetapkan di Desa Sidorejo Kecamatan Sawahan Kabupaten Nganjuk. Pemilihan lokasi penelitian didasarkan pertimbangan bahwa Desa Sidorejo Kecamatan Sawahan Kabupaten Nganjuk merupakan Desa yang terindikasi tidak terlalu mengalami kemajuan dilihat dari sektor pembangunan.

Sumber data pada penelitian ini didapatkan dari orang, benda atau objek yang bersifat relevan dimana keterkaitan dengan masalah yang di teliti. Sumber data pada penelitian ini berasal dari seluruh masyarakat desa Sidorejo, dengan informan penelitian terdiri dari 5 orang informan yaitu : kepada Desa Sidorejo, Kepala urusan pembangunan 2 orang serta tokoh masyarakat sebanyak 2 orang. Dengan dua jenis sumber data(Soewadji, 2012) yaitu primer :data yang diperoleh dengan melakukan penelitian secara langsung dari responden yang diinginkan oleh peneliti dengan menggunakan teknik pengumpulan data dari hasil observasi dan wawancara atau interview. Dan data sekunder merupakan data yang diperoleh secara tidak langsung dari objek yang diteliti antara lain bersumber dari sumber-sumber studi pustaka (library research) untuk mengumpulkan data-data melalui buku -buku, peraturan-peraturan, arsip / laporan.

Teknik analisa data yang di gunakan pada penelitian ini adalah menggunakan teori yang dikemukakan oleh(Miles \& Huberman, 1994)dalam buku yang telah direvisi mengemukakan bahwa Perbedaan data yang baru dengan yang lama adalah terletak pada, data reduction di ganti dengan condensation. Miles dan Huberman menuliskan Data Condensation refers to the process of selecting, focusing, simplifying, abstracting, and/or transforming the data that appear in the full corpus (body) of written up field 
notes, interview transkrip, documents, and other empirical materials. By condensing, we are making data stronger.(Sugiono, 2016)

\section{HASIL DAN PEMBAHASAN}

Keberhasilan dalam pembangunan di suatu desa sangat berhubungan dengan tingkat partisipasi masyarakat yang ada didesa tersebut, baik dari sistem atausebagai individu dimana menjadi faktor penting dari proses suatu pembangunan. Tingkat keberhasilan suatu pembangunan dapat dilihat dari partisipasi masayarakat yang terlibat dalam proses pembangunan. Oleh sebab itu keberhasilan pembangunan bukan hanya dari pemerintahan namun juga perlu adanya campur tangan langsung dari masayarakat untuk mencapai tujuan bersama untuk mensejahterkan masyarakat di Desa Sidorejo.

Dalam proses perencanaan pembangunan pemerintahan desa Sidorejo tidak melibatkan secara langsung masyarakat dalam pertemuan musrengbangdes, padahal semakin tinggi partisipasi masyarakat akan semakin banyak pula program kerja yang akan diusulkan oleh masyarakat guna untuk memajukan desa atau memperbaiki fasilitas dilingkungan masing-masing. Tentunya dalam perencanaan pembangunan serta pengambilan keputusan tidak jauh dari persetujuan masyarakat, namun masyarakat umum hanya dapat memberikan usul atau gagasan yang hanya mampu dijembatani oleh RT dan RW setempat, dimana dalam pertemuan musrengbangdes hanya melibatkan beberapa kalangan yaitu semua aparatur pemerintahan desa, tokoh masyarakat serta RW dan RT sebagai lapisan terendah yang menjadi jembatan antara pemerintahan desa dengan masyarakat setempat dimana RT dan RW akan secara langsung mensosialisasikan hasil keputusan musyarawarah musrengbangdes kepada warga setempat sesuai dengan lingkungan masing-masing. Namun dapat dilihat juga banyak program pembangunan yang setiap tahunnya tidak dilaksanakan dengan alasan dana. Dapat ditarik garis besar bahwa partisipasi masyarakat dalam perencanaan pembangunan masih baik karena masih banyak usulan dari masyarakat yang diterima pemerintah desa Sidorejo guna untuk merawat dan mengembangkan potensi dari Desa Sidorejo. Sedangkan untuk ketidak terlibatan beberapa masyarakat dalam perencanaan pembangunan merupakan hal wajar yang mampu dimaklumi. Karena hal tersebut terjadi 
karena masyarakat hanya mampu mengeluarkan apresiasi secara tidak langsung. Dengan begitu banyak masyarakat yang bersikap proaktif.

Partisipasi masyarakat dalam pelaksanaan pembangunan dapat dijelaskan bahwa setiap pelaksanaan pembangunan pemerintahan yang bersifat formal maka akan ada gaji yang diberikan oleh pemerintah desa. Kegiatan bersifat formal ini berupa pembangunan jalan, pembukaan jalan baru, pembangunan dinding penahan tanah disamping-samping rumah warga, dengan begitu dalam pelaksanaan pembangunan yang bersifat sukarelawan hanyalah terjadi ketika diadakannya gotong-royong antar tetangga maupun antar lingkungan masing-masing. Sedangkan dalam pelaksanaan pembangunan desa ada perbedaan yang mendasari yaitu partisipasi bersifat formal dari pemerintah Desa Sidorejo yang dimana setiap kegiatan pelaksanaan tersebut dibayar/digaji oleh pemerintah Desa Sidorejo. Dan partisipasi yang bersifat gotong royong antar warga masyarakat. adanya fasilitas yang memadai serta sumber daya manusia atau penduduk yang berada di Desa Sidorejo dapat digolongkan cukup tinggi. Mengapa dapat disimpulkan seperti itu karena hal tersebut yang sangat berkaitan erat dengan keberhasilan suatu Desa. Hal pokok partisipasi dalam pembangunan sangat bergantung dari adanya keterlibatan masyarakat secara langsung pada pelaksanaan pembangunan desa, keterlibatan masyarakat disini baik berupa tenaga maupun sumbangan dana. Namun untuk sumbangan dana tidak untuk proses pelaksanaan pembangunan di Desa Sidorejo sudah tidak ada, karena semua kebutuhan pembangunan menjadi tanggungjawab pemerintahan Desa Sidorejo. Masyarakat setempat kadang kala hanya menyiapkan makanan kecil secara cuma-cuma untuk para pekerja sebagai rasa saling gotong-royong atau membelikan material bangunan secara mandiri jika ada tambahan menuju masing-masing rumah. Dengan adanya hal tersebut dapat dilihat adanya keterlibatan masyarakat secara langsung dalam pembangunan yang sedang berjalan, dengan menunjukkan rasa kepedulian dan sifat gotong-royong yang tidak dapat dipisahkan dalam kehidupan pedesaan. Karena sifat gotong-royong adalah mencerminkan dimana adanya rasa kepedulian yang tinggi dari masyarakat desa. Sedangkan pelaksanaan pembangunan desa tanpa adanya kesadaran dari masyarakatnya 
secara sadar maka dapat dikategorikan bahwa pelaksanaan pembangunan tersebut tidak baik, karena pelaksanaan pembangunan dapat dikatakan baik jika didalam pelaksanaan pembangunan tersebut mencerminkan adanya sifat bantuan atau partisipasi masyarakat dengan rasa kepedulian penuh tanpa adanya paksaan atau imbalan lainnya karena disini ditekankan dengan rasa sepenuh hati. Adapun hal-hal yang sangat berdampak pada partisipasi dalam pelaksanaan pembangunan desa adalah rasa egois dari masing-masing individu yang terlalu sibuk dengan kesibukannya sendiri. Sedangkan faktor dari keberhasilan suatu pembangunan desa adalah partisipasi masyarakat dengan kesadaran yang tinggi. Sesuai dengan hasil yang telah didapatkan oleh peneliti maka dapat dijabarkan sebagai berikut, bahwa partisipasi masyarakat dalam pelaksanaan di Desa Sidorejo sudah cukup baik. Pernyataan tersebut dapat dilihat dari adanya keterlibatan langsung dari masyarakat Desa Sidorejo dalam pelaksanaan pembangunan di Desa Sidorejo. Dalam pelaksanaan pembangunan di Desa Sidorejo pemerintah desa wajib untuk memfasilitasi semua kebutuhan dalam pelaksanaan pembangunan baik dari hal kecil hingga hal besar. Tentunya pemfasilitasan dalam proses pembangunan diambilkan dari dana Desa yang keluar setiap tahunnya. Untuk seluruh masyarakat yang terlibat dalam pelaksanaan pembangunan akan nada upah/ gaji dari pemerintah Desa Sidorejo. Sehingga pelaksanaan pembangunan bukan hanya berfungsi untuk menambah atau memperbaiki fasilitas desa namun juga mampu membuka peluang pekerjaan bagi masyarakat setempat dalam waktu tertentu,dimana Kasi Pelayanan dan Pembangunan menyebutkan bahwa gaji dari keterlibatannya masyarakat dalam pelaksanaan pembangunan lebih besar dari pada pekerjaan pembangunan biasanya. Dengan begitu dengan diadakannya pelaksanaan pembangunan namun, mengandung manfaat mensejahterakan masyarakat Desa Sidorejo Kecamatan Sawahan Kabupaten Nganjuk.

Sedangkan untuk partisipasi masyarakat dalam pengawasan pembangunan dapat dijabarkan juga sebagai sebuah tanda bahwa dalam proses pembangunan desa sudah dilaksanakan hingga sampailah pada tahap terakhir adalah partisipasi pengawasan dari diadakannya pembangunan. Partisipasi pengawasan adalah proses akhir dari hasil pembangunan desa, partisipasi pengawasan disini berguna untuk menilai, mengontrol 
serta mengevaluasi dari jalannya pembangunan yang telah dilaksanakan. Proses pengawasan dari adanya pembangunan yang telah dilakukan juga berguna untuk pembelajaran pembangunan kedepannya. Hal yang sangat disayangkan dari partisipasi masyarakat dalam pembangunan Desa Sidorejo ialah tidak adanya Proses pengawasan secara formal. Dengan tidak diadakannya pertemuan tersebut maka tidak ada pembahas hasil-hasil dari pembangunan yang dilaksanakan,tidak hanya membahas hasil yang telah dicapai namun pada pertemuan yang dilaksanakan banyak dari masyarakat perwakilan yang menyuarakan pendapat, kritik serta saran yang dibahas bersama hingga mampu menghasilkan suatu gerakan dimana pemerintah desa lebih memahami rakyat dengan begitu dapat diharapkan untuk pembangunan kedepan dapat dijadikan contoh agar kesalahan tidak terulang kembali. Karena tidak diadakannya kegiatan tersebut maka kritik saran hanyalah sebagai unek-unek yang tidak tepat sasaran. Sehingga diharapkannya untuk setiap proses pembangunan seharusnya diadakan urutan pembangunan yang baik, yang diawali dengan perencanaan pembangunan, pelaksanaan pembangunan dan pengawasan dari pembangunan guna untuk menunjang adanya kualitas yang baik antara pemerintahan Desa Sidorejo dengan masyarakat Desa Sidorejo.

\section{KESIMPULAN}

Berdasarkan uraian dari hasil yang telah dijabarkan maka dapat disimpulkan bahwa Partisipasi masyarakat dalam pembangunan desa di Desa Sidorejo Kecamatan Sawahan Kabupaten Nganjuk dinilairelatif tinggi, hal tersebut didasarkan pada : Dalam perencanaan pembangunan partisipasi ditunjukkan dengan keaktifannya dalam memberikan pendapat atau masukan pada saat dilaksanakan musyawarah perencanaan pembangunan (musrenbang). Dalam pelaksanaan pembangunan partisipasi yang ditunjukkan adalah dengan memberikan bantuan baik material yang biasanya berupa bahan material bangunan, tenaga, serta konsumsi. Dalam pengawasan pembangunan, partisipasi ditunjukkan apabila ada pembangunan yang tidak sesuai maka masyarakat mengadukan kepada pihak yang terkait.Sedangkan faktor-faktor yang mendukung partisipasi masyarakat dapat ditinjau dari diberikannya ruang atau kesempatan untuk 
masyarakat Desa Sidorejo Kecamatan Sawahan Kabupaten Nganjuk menggali potensi yang dimiliki, maka masyarakat dapat ikut andil dalam proses perencanaan atau pelaksanaan pembangunan. Untuk sejauh ini faktor penghambat yang benar-benar berdampak pada pelaksanaan pembangunan tidak di temukan.

Berdasarkan kesimpulan diatas menunjukkan bahwa partisipasi masyarakat Desa Sidorejo relatife tinggi, hendaknya partisipasi masyarakat itu perlu ditingkatkan atau minimal dipertahankan.maka saran dari peneliti adalah :Partisipasi masyarakat Desa Sidorejo dalam pembangunan perlu ditingkatkan, serta peran dari pemerintah Desa juga harus bekerja lebih giat serta transparan dalam hal proses pembangunan baik dari proses perencanaan, pelaksanaan, hingga pengawasan agar tidak banyak terjadi silang paham antara masyarakat dengan aparatur pemerintah desa. Dalam proses perencanaan pembangunan seharusnya setelah diputuskannya hasil dari musyawarah musrengbangdes dalam pelaksanaan pembangunan, harus disosialisasikan kepada masyarakat secara langsung oleh ketua RT dan RW yang di dampingi oleh perwakilan pemerintah desa. Serta dalam hal pengawasan seharusnya juga diadakannya rapat terakhir setelah pelaksanaan pembangunan selesai. Kegiatan rapat setelah pembangunan tersebut diharapkan mampu menjadi bahan evaluasi untuk pembangunan selanjutnya.

\section{REFERENSI}

Daraba, D. 2017. Pengaruh Program Dana Desa terhadap Tingkat Partisipasi Masyarakat di Kecamatan Galesong Utara Kabupaten Takalar. Sosiohumaniora, 19(1), 52-58.

Ibrahim, M. A. 2015. Metodologi penelitian kualitatif. Bandung: Alfabeta.

Indrawidjaja, A. I., Pranoto, J., Riduwan, Sukari, \& Subandi. 2011. Revitalisasi administrasi pembangunan: berbasis jatidiri dan karakter bangsa dalam pembangunan nasional. Alfabeta.

Letsoin, H. 2015. Partisipasi Masyarakat dalam Pelaksanaan Pembangunan di Desa Coa Distrik Kaimana Kabupaten Kaimanal. JURNAL POLITICO, 4(1).

Miles, M. B., \& Huberman, A. M. 1994. Qualitative data analysis: An expanded sourcebook. sage.

Sari, I. P. 2016. Implementasi Pembangunan Partisipatif ( Studi Kasus Di Kelurahan Andowia Kabupaten Konawe Utara). Jurnal Ekonomi (JE), 1(April), 179-188. 
SIHITE, W. R., \& ZAKARIA, Z. 2017. Partisipasi Masyarakat dalam Pembangunan Desa pada Program Gerbang Swara. Politeia: Jurnal Ilmu Politik, 9(1).

Soewadji, J. 2012. Pengantar metodologi penelitian. Jakarta: Mitra Wacana Media, 210.

Sugiono, S. 2016. Metode Penelitian Kuantitatif, Kualitatif, dan $R \& D$. Bandung: Alfabeta.

Suseno, D. A., \& Sunarto, S. T. 2016. Analisis Perencanaan Pembangunan Desa Berbasis Undang-Undang Desa No 6 Tahun 2014 Di Kecamatan Gunungpati Kota Semarang. JURNAL STIE SEMARANG (EDISI ELEKTRONIK), 8(2), 122-137.

Suyono, D., \& Pramono, T. 2018. Reformasi Birokrasi Di Badan Pusat Statistik Kabupaten Tulungagung. Mediasosian, Vol. 2(2), hal. 25-31. 